\title{
ANALISIS BUDAYA “PIIL PESENGGIRI” DALAM PENINGKATAN BUDAYA KERJA APARATUR DI BALAI DESA SABAH BALAU KABUPATEN LAMPUNG SELATAN
}

\author{
Ayu Nadia Pramazuly ${ }^{1}$, Hinfa Mosshananza ${ }^{2}$ Rosidah $^{3}$ \\ ayunadiapramazuly@gmail.com¹ hinfamosshananza@gmail.com² idahros40@gmail.com³ \\ $[1][2][3]$ Program Studi Administrasi Publik, Fakultas Ilmu Sosial dan Ilmu Politik, UTB Lampung
}

\begin{abstract}
ABSTRAK
Tujuan penelitian ini adalah untuk mengetahui pemahaman budaya "Piil Pesenggiri" dan penerapan budaya tersebut dalam upaya meningkatkan budaya kerja aparatur desa. Permasalahan yang diangkat dalam penelitian ini yaitu seiring kemajuan jaman yang semakin memudarkan budaya Lampung menjadi tantangan bagi masyarakat khususnya aparatur pemerintahan mempertahankan dan menerapkan ke dalam budaya kerja sehingga dapat meningkatkan kinerja yang berkualitas. Jenis penelitian yang digunakan yaitu deskriptif kualitatif dengan lokasi penelitian di Balai Desa Sabah Balau Kabupaten Lampung Selatan. Penelitian ini diharapkan dapat menjadi pandangan untuk pembangunan yang lebih baik lagi khususnya pemerintahan Desa Sabah Balau. Penelitian ini diharapkan dapat menjadi pandangan untuk pembangunan yang lebih baik lagi khususnya pemerintahan Desa Sabah Balau.
\end{abstract}

Kata Kunci: Piil Pesenggiri,Budaya Kerja

\section{PENDAHULUAN}

Salah satu budaya lokal Lampung dikenal dengan Budaya Piil Pesenggiri merupakan falsafah tua yang menjadi pandangan hidup masyarakat Lampung. Namun, pada kenyataannya seiring perkembangan jaman budaya tersebut kian tenggelam dan tidak sedikit banyak yang melupakan. Masyarakat Lampung terkenal dengan "Piil" yaitu sebutan lain dari Piil Pesenggiri yang artinya harga diri. Pemaknaan dari "Piil" saat ini jauh dari arti atau makna yang sesungguhnya. Artinya, masyarakat sekarang memaknai budaya tersebut dengan sebuah harga diri, baik untuk pandangan positif maupun negatif. sehingga tidak jarang dapat memicu perselisihan karena merasa harga dirinya dijatuhkan.

Salah satu kemajuan dunia ditandai munculnya globalisasi dan pasar bebas menuntut budaya lokal semakin sulit berkembang dan dilestarikan. Menurut Selo Soemardjan menyatakan adanya kategori adat dalam suatu pemerintahan tersebut menghendaki adanya persepsi bahwa kedaerahan di Indonesia adalah pluralistik. Kebhinekaan adat istiadat akan memunculkan pelayanan publik yang berbeda-beda dari tiap daerah dalam proses penyelenggaraan pemerintahannya. Paradigma pemerintahan yang masih mengedepankan adat istiadat biasanya dapat dengan mudah ditemukan di daerah-daerah yang 
masih kental akan kebudayaannya. Pada otonomi daerah terdapat tiga fungsi pemerintahan yaitu fungsi penyelenggaraan pemerintahan, penyelenggaraan pembangunan dan penyelenggaraan pelayanan kepada masyarakat. Sebagai penyelenggaraan pemerintahan, pemerintah dituntut menyelesaikan permasalahan yang ada di masyarakat selain menjalankan program kerja yang sudah direncanakan. Untuk itu, pemerintah wajib memiliki karakter yang kuat dan bijaksana agar mampu bertahan di era globalisasi yang penuh dengan tantangan dan hambatan.

Dalam

penyelenggaraan pemerintahan, aspek pendukung selain sumber daya manusia adalah budaya kerja. Hal ini menjadi fokus dalam melaksanakan program-program pembangunan. Penerapan budaya kerja patut menjadi perhatian melihat saat ini aparatur pemerintah masih lalai dalam menjalankan kewajibannya terbukti maraknya penangkapan aparatur pemerintah yang terjerat korupsi. Kinerja aparatur pemerintah sering kali dibandingkan dengan kinerja karyawan swasta yang memiliki etos kerja yang tinggi. Pedesaan memiliki karakter penyelenggaraan pemerintahan yang berbeda dengan perkotaan. Kearifan lokal masyarakat masih kental sekalipun dalam menyelenggarakan pemerintahan yang saat ini dibebankan kepada Kepala Desa. Salah satunya Desa Sabah Balau Lampung Selatan yang terletak di perbatasan antara Kota Bandar
Lampung dengan Kabupaten Lampung Selatan. Balai desa menjadi tempat pengaduan dan pelayanan bagi masyarakat yang memiliki kepentingan dengan pemerintah.

\section{TINJAUAN PUSTAKA}

\subsection{Tinjauan tentang Budaya Piil Pesenggiri}

Piil Pesenggiri adalah tatanan moral yang merupakan pedoman bersikap dan berperilaku masyarakat adat Lampung dalam segala aktivitas hidupnya. Falsafah hidup orang Lampung sejak terbentuk dan tertatanya masyarakat adat adalah piil pesenggiri. Piil Pesenggiri selaku tatanan moral membagikan pedoman bagi perilaku pribadi dan masyarakat adat Lampung yang berupaya membangun karyakaryanya. Piil Pesenggiri pada hakikatnya ialah nilai dasar yang intinya terletak pada keharusan untuk mempunyai hati nurani yang positif (bermoral tinggi dan berhati besar), sehingga senantiasa dapat hidup secara logis, etis dan estetis. Secara ringkas unsur-unsur Piil Pesenggiri dapat dijelaskan sebagai berikut :

\section{a. Juluk-adek (Inovatif)}

Secara etimologis Juluk-adek terdiri dari kata juluk dan adek, yang masingmasing mempunyai makna; Juluk adalah nama panggilan keluarga seorang pria/wanita yang diberikan pada waktu mereka masih muda atau remaja yang belum menikah, dan adek 


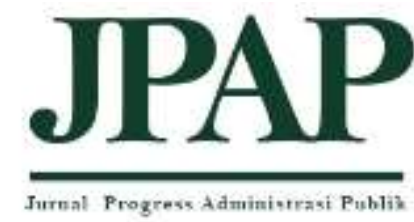

Volume 1 Nomor 2

bermakna gelar/nama panggilan adat seorang pria/wanita yang sudah menikah melalui prosesi pemberian gelar adat. Juluk-adek merupakan hak bagi anggota masyarakat Lampung, oleh karena itu julukadek merupakan identitas utama yang melekat pada pribadi yang bersangkutan. Biasanya penobatan juluk-adek ini dilakukan dalam suatu upacara adat sebagai media peresmiannya. Juluk-adek ini biasanya mengikuti tatanan yang telah ditetapkan berdasarkan hirarki status pribadi dalam struktur kepemimpinan adat.

\section{b. Nemui-nyimah (Produktif)}

Nemui berasal dari kata benda temui yang berarti tamu, kemudian menjadi kata kerja nemui yang berarti bertamu atau mengunjungi / silaturahmi. Nyimah berasal dari kata benda "simah", kemudian menjadi kata kerja "nyimah" yang berarti suka memberi (pemurah). Sedangkan secara harfiah nemui- nyimah diartikan diartikan sebagai sikap santun, pemurah, terbuka tangan, suka memberi dan menerima dalam arti material sesuai dengan kemampuan. Nemui-nyimah merupakan ungkapan asas kekeluargaan untuk menciptakan suatu sikap keakraban dan kerukunan serta silaturahmi. Nemui-nyimah merupakan kewajiban bagi suatu keluarga dari masyarakat Lampung umumnya untuk tetap menjaga silaturahmi, dimana ikatan keluarga secara genealogis selalu terpelihara dengan prinsip keterbukaan, kepantasandan kewajaran.

\section{c. Nengah-nyappur (Kompetitif)}

Nengah berasal dari kata benda, kemudian berubah menjadi kata kerja yang berarti berada di tengah. Sedangkan nyappur berasal dari kata benda cappur menjadi kata kerja nyappur yang berarti baur atau berbaur. Secara harfiah dapat diartikan sebagai sikap suka bergaul, suka bersahabat dan toleran antar sesama. Nengah-nyappur menggambarkan bahwa anggota masyarakat Lampung mengutamakan rasa kekeluargaan dan didukung dengan sikap suka bergaul dan bersahabat dengan siapa saja, tidak membedakan suku, agama, tingkatan, asal usul dan golongan. Sikap suka bergaul dan bersahabat menumbuhkan semangat suka bekerjasama dan tenggang rasa (toleransi) yang tinggi antar sesamanya.

\section{d. Sakai-sembayan (Kooperatif)}

Prinsip Sakai Sambayan yang pada hakikatnya adalah menunjukkan rasa partisipasi yang dalam serta solidaritas yang tinggi pada masyarakat terhadap sesuatu kegiatan atau kewajiban yang harus dilakukan. Sakai bermakna memberikan sesuatu kepada seseorang atau sekelompok orang dalam bentuk benda dan jasa yang bernilai ekonomis yang dalam prakteknya cenderung menghendaki saling berbalas. Sedangkan sambaiyan bermakna memberikan sesuatu kepada seseorang, 
sekelompok orang atau untuk kepentingan umum secara sosial berbentuk benda dan jasa tanpa mengharapkan balasan.

\subsection{Tinjauan tentang Budaya Kerja}

\section{a. Pengertian Budaya Kerja}

Pengertian kebudayaan banyak dikemukakan oleh para ahli seperti Koentraningrat, yaitu kebudayaan adalah keseluruhan manusia dari kelakuan dan hasil kelakukan yang teratur oleh tata kelakuan yang harus didapatnya dengan belajar dan semuanya tersusun dalam kehidupan masyarakat. Sedangkan pengertian budaya kerja menurut Hadari Nawawi dalam bukunya Manajemen Sumber Daya Manusia menjelaskan bahwa Budaya Kerja adalah kebiasaan yang dilakukan berulangulang oleh pegawai dalam suatu organisasi, pelanggaraan dengan kebiasaan ini memang tidak ada sangsi tegas, namun dari pelaku organisasi secara moral telah menyepakati bahwa kebiasaan tersebut merupakan kebiasaan yang harus ditaati dalam rangka pelaksanaan pekerjaan untuk mencapai tujuan.

\section{b. Unsur-unsur Budaya Kerja}

Menurut Taliziduhu Ndraha,
budaya kerja dapat dibagi
menjadi dua unsur, yaitu:

1. Sikap dengan pekerjaan, yakni kesukaan akan kerja dibandingkan dengan kegiatan lain, seperti bersantai, atau semata-mata memperoleh kepuasan dari kesibukan pekerjaannya sendiri, atau merasa terpaksa melakukan sesuatu hanya untuk kelangsungan hidupnya.

2. Perilaku pada waktu bekerja, seperti rajin, berdedikasi, bertanggung jawab, berhati-hati, teliti, cermat, kemauan yang kuat untuk mempelajari tugas dan kewajibannya, suka membantu sesama pegawai, atau sebaliknya.

\section{c. Manfaat Budaya Kerja}

Budaya kerja memiliki tujuan untuk mengubah sikap dan juga perilaku SDM yang ada agar dapat meningkatkan produktivitas kerja untuk menghadapi berbagai tantangan di masa yang akan datang. Manfaat dari penerapan Budaya Kerja yang baik:

1. Meningkatkan jiwa gotong royong

2. Meningkatkan kebersamaan

3. Saling terbuka satu sama lain

4. Meningkatkan jiwa kekeluargaan

5. Meningkatkan rasa kekeluargaan

6. Membangun komunikasi yang lebih baik

7. Meningkatkan produktivitas kerja

8. Tanggap dengan perkembangan dunia luar 


\section{METODE}

\subsection{Jenis Penelitian}

Penelitian ini menggunakan metode penelitian dengan pendekatan kualitatif. Menurut Moleong (dalam bukunya Haris hardiansyah) mengemukakan bahwa : "Penelitian kualitatif adalah prosedur penelitian yang menggunakan data deskriptif berupa kata-kata tertulis atau lisan dari orang-orang dan perilaku yang dapat diamati. Penelitian ini menyusun desain yang secara terus menerus disesuaikan dengan kenyataan di lapangan. Penelitian kualitatif tidak bertujuan untuk mengkaji atau membuktikan kebenaran suatu teori tetapi teori yang sudah ada dikembangkan dengan menggunakan data yang dikumpulkan". Pada penelitian ini, setelah peneliti mengumpulkan data dalam bentuk hasil wawancara, dokumentasi, dan observasi maka untuk selanjutnya data tersebut akan dianalisis lebih mendalam lagi sehingga membentuk suatu kesimpulan ilmiah-alamiah yang dapat diterima oleh berbagai kalangan, terutama dalam hal ini adalah Pemerintah Desa dan Masyarakat Sabah Balau Kabupaten Lampung Selatan.

\subsection{Jenis Data}

Jenis data pada penelitian ini dibedakan menjadi 2 (dua) yaitu:

1. Data Primer.

2. Data Sekunder

\subsection{Lokasi Penelitian}

Pada penelitian ini adapun yang menjadi lokasi penelitian adalah Desa Sabah Balau Kabupaten Lampung Selatan.

\subsection{Teknik Pengumpulan Data}

Teknik pengumpulan data yang digunakan dalam penelitian ini adalah :

1. Wawancara

2. Dokumentasi

\subsection{Teknik Analisis Data}

Analisis data dalam bukunya Sugiyono adalah proses mengatur urutan data kedalam suatu pola, kategori dan satuan uraian besar. Analisis data menggunakan analisis deskriptif yang sipatnya induktif (kesimpulan khusus menjadi umum), yaitu berusaha untuk memperoleh kesimpulan berdasarkan pemikiran yang alamiah dari berbagai jawaban yang diperoleh atau mencoba mendalami dan meneropong gejala social-politik dengan menginterpretasikan masalah yang terkandung di dalamnya.

\section{ANALISIS HASIL DAN PEMBAHASAN}

\subsection{Budaya Kerja Aparatur Balai Desa Sabah balau}

Pembentukan budaya kerja terjadi tatkala lingkungan kerja atau organisasi belajar menghadapi masalah, baik yang menyangkut perubahan-perubahan ekternal maupun internal yang 
menyangkut persatuan dan keutuhan organisasi (Sithi dalam ndraha, 2003:76). Dengan demikian, budaya kerja bertujuan untuk mengembangkan sikap produktif, kooperatif, kompetitif dan inovatif individu sebagai modal dalam menghadapi perkembangan zaman di masa yang akan datang. Apabila ke empat indikator di atas terpenuhi dengan maksimal maka akan tercipta budaya kerja yang baik. Penilaian budaya kerja dapat dirasakan langsung oleh penerima layanan dalam hal ini masyarakat maupun pimpinan serta rekan kerja.

Produktivitas (Nemui-nyimah) dalam pelakasanaan tugas aparatur Balai Desa Sabah Balau telah sesuai dengan jobdesk yang diberikan oleh pimpinan. Di Balai ini terdapat 7 (tujuh) perangkat desa yang memiliki tugas dan fungsi masing-masing. Seperti yang kita ketahui perangkat desa meskipun di bawah naungan Pemerintah tetapi tidak semua perangkat desa adalah Aparatur Sipil Negara (ASN). Di desa ini sendiri hanya memiliki 1 (satu) perangkat desa yang menjabat sebagai ASN. Desa sabah Balau tidak memiliki program kerja yang teragenda. Seluruh kegiatan masih bergantung pada kegiatan pusat maupun kecamatan. Dengan demikian, Budaya Kerja Desa sabah balau belum Inovatif (Julukadek). Desa masih mengandalkan kegiatan ataupun program kerja dari Kecamatan. Dengan kata lain tidak ada program kerja maka tidak ada pekerjaan.

Kades menambahkan bahwa kinerja pegawainya sendiri diakui kebanyakan diambil alih olehnya, sehingga tidak jarang kades melakukan studi banding ke desa- desa tetangga. Ketidak cekatan pegawainya pun ditanggapi dengan tegas, bahwa sesuatu yang tidak dikerjakan sungguh-sungguh maka hasilnya tidak akan maksimal. Jika ada kemauan, yang tidak tahu maka cari tahu, yang tidak bisa maka belajar hingga bisa.

\subsection{Perlunya Peningkatan Budaya Kerja Aparatur Balai Desa Sabah Balau}

Melihat perkembangan zaman yang diikuti perkembangan ilmu dan era digital, maka dipandamg perlu untuk meningkatkan budaya kerja. Peningkatan budaya kerja berpengaruh besar dengan tingkat disiplin. Seperti yang telah dibahas sebelumnya, disiplin merupakan masalah utama rendahnya budayakerja aparatur desa Sabah Balau. Tujuan meningkatkan budaya kerja yatu untuk menghasilkan Aparatur yang disiplin, pikiran yang disiplin, dan perilaku yang disiplin.

\subsection{Hambatan - hambatan dalam Peningkatan Budaya Kerja Aparatur}

Ada beberapa indikator yang menjadi hambatan dalam meningkatkan budaya kerja aparatur di Balai Desa Sabah Balau, misalnya tingkat pendidikan aparatur desa. Kebijakan kepala desa untuk menunjuk aparaturnya dan kebanyakan aparatur desa merupakan lulusan sekolah menengah atas. 
Penyebab lainnya, minimnya kesejahteraan yang didapat oleh aparatur sehingga pekerjaan ini bersifat pengabdian. Hambatan lainnya yaitu fasilitas baik sarana maupun prasarana. Hingga saat ini, kantor balai desa belum memiliki bangunan resmi. Bangunan yang ada merupakan hasil wakaf dari warga. Wacana untuk memiliki kantor permanen juga telah menjadi prioritas dalam pembangunan desa sabah balau. Yang terakhir hambatan dari diri aparatur, yaitu kurangnya motivasi diri. Bekerja sebagai aparatur desa merupakan tugas pengabdian masyarakat. sedangkan segala kebutuhan saat ini diorientasikan dengan uang sehingga aparatur dituntut berpikir realistis.

\section{REFERENSI}

Herdiansyah, Haris. 2010. Metodologi Penelitian Kuantitatif. Salemba Humanika. Jakarta

Koentraningrat. 2004. Kebudayaan Mentalitet dan Pembangunan. PT. Gramedia. Jakarta

Moekijat. 2006. Asas-asas Perilaku Organisasi. CV. Mandar Maju. Bandung.

Nawawi, Hadari. 2003. Manajemen Sumber Daya Manusia. UGM Press. Yogyakarta.

Ndraha, Taliziduhu. 2003. Teori Budaya Organisasi. PT. Rineka Cipta. Jakarta.

Prasetya, Triguno. 2001. Manajemen Sumber Daya Manusia. PT. Bumi Aksara. Jakarta.

Soemardjan, Selo. Perubahan Sosial di Yogyakarta. Komunitas Bambu. Depok
Sugiyono. 2008. Metode Penelitian Kualitatif dan Kuantitatif. Alfabeta. Bandung.

Supriyadi, Gering dan Triguno. 2001. Budaya Kerja Organisasi Pemerintah. LAN. Jakarta.

Syani, Abdul. 2014. Kearifan Lokal Lampung. Universitas Lampung Press. Lampung

Umar, Husen. 2008. Metode Penelitian Untuk Skripsi dan Tesis Bisnis. PT. Rajagrafindo Persada. Jakarta.

\section{Sumber Lain:}

Skripsi Annisa Yudi Nuranggun. 2011. Pengaruh Piil Pasenggiri Terhadap Prilaku Birokrasi Pelayanan Publik. Universitas Lampung. Lampung

\section{Website :}

$\begin{array}{lrr}\text { Artikel Abdul } & \text { Sany, } & \text { "Falsafah } \\ \text { Hidup } & & \text { Masyarakat } \\ \text { Lampung } & \text { Sebuah } & \text { Wacana } \\ \text { Terapan”, } & \text { diaskses pada } \\ \text { http://staff.unila.ac.id/abdulsyani/ } \\ \text { 2013/ }\end{array}$

